\title{
The Economic Succession Doctrine in Private Enforcement of EU Competition Law: 'Nothing Extraordinary' after Skanska Industrial?*
}

\author{
Marco Botta**
}

ABSTRACT: The article analyses the recent judgment of the Court of Justice of the European Union (CJEU) in Skanska Industrial. In its preliminary ruling, the CJEU recognised for the first time the so-called "economic succession doctrine" in damage claims concerning a breach of EU competition rules. In the judgment, the CJEU relied on its well-established case law. From this point of view, the ruling is "nothing extraordinary". Nevertheless, the judgment represents an important milestone that contributes to the development of damage claims in Europe.

The article first discusses the origins of the economic succession doctrine, which derives from the broad concept of "undertaking" developed by the CJEU case law and the so-called "single economic entity" doctrine. Afterwards, the article discusses the Skanska Industrial case, in particular by comparing the opinion of Advocate General (AG) Wahl with the CJEU ruling in the case. The article concludes by discussing the potential consequences of the CJEU ruling in Skanska Industrial on private enforcement of EU competition law, as well as the questions that remain open after the judgment.

After Skanska Industrial, it remains unclear how the disclosure of evidence will take place in practice in the context of a damage claim following a corporate restructuring. Secondly, the limits of the economic succession doctrine remain unclear: it is unclear when a corporate restructuring indeed leads to the establishment of a "new" undertaking, free from the antitrust liability acquired by its predecessor. Finally, it remains unclear whether Skanska Industrial case law could also be extended to other remedies besides damage claims, such as actions requesting a court injunction, compensation for unjust enrichment, or a declaration that a contract is null and void. The article

\footnotetext{
* DOI: https://doi.org/10.7559/mclawreview.2019.1828.

** Max Planck Institute for Innovation and Competition, Munich (Germany). Marco.botta@ ip.mpg.de.
} 
argues that in the coming years the CJEU will probably be called to clarify Skanska Industrial case law in order to answer these remaining questions.

KEYWORDS: Economic succession doctrine, single economic entity doctrine, private enforcement of EU competition law, damage claims, preliminary ruling

\section{Introduction}

On 14 March 2019, the Court of Justice of the European Union (CJEU) delivered its landmark ruling in Skanska Industrial. ${ }^{1}$ The case originates from a request for preliminary ruling submitted by the Finnish Supreme Court. In its essence, the case concerns the application of the so-called "economic succession doctrine" in damage claims concerning a breach of EU competition law. This important issue had not been clarified by the Damages Directive. ${ }^{2}$ The CJEU's preliminary ruling, therefore, should be welcomed, since it sheds light on an important aspect for the development of antitrust damage claims in Europe. However, as further discussed in the following sections, the judgment also leaves some questions open, which will probably have to be further clarified by the Court in its future jurisprudence.

After an explanation of the origins of the economic succession doctrine and its relevance in public enforcement of EU competition law, the article discusses the Skanska Industrial case. In particular, after an overview of the national proceedings that led to the request of preliminary ruling, the article compares the opinion of Advocate General (AG) Wahl with the CJEU's ruling in the case. The article concludes by discussing the potential consequences of the CJEU's ruling in Skanska Industrial on private enforcement of EU competition law, as well as the questions that remain open after the judgment.

\section{From the single economic entity to the economic succession doctrine}

The origins of the economic succession doctrine discussed by the CJEU in Skanska Industrial stem from the concept of "undertaking" under EU law.

\footnotetext{
${ }^{1}$ Judgment of 14 March 2019, Vantaan kaupunki v. Skanska Industrial Solutions Oy e a., C-724/17, ECLI:EU:C:2019:204.

2 Directive 2014/104/EU of the European Parliament and of the Council of 26 November 2014 on certain rules governing actions for damages under national law for infringements of the competition law provisions of the Member States and of the European Union. OJ L-349/1, 5.12.2014.
} 
Several provisions of the Treaty of Rome referred to the word "undertaking" without however providing a clear definition of this concept. ${ }^{3}$ This is not surprising: when the Treaty was drafted, the definition of entreprise in France was quite different from the concept of Unternehmen in Germany or impresa in Italy. The definition of undertaking had, in fact, deep roots in national corporate law and was different in every Member State. Since the EU founding fathers could not find an agreement on what represented an undertaking in the Treaty, they left to the Court of Justice the task of clarifying this legal concept.

In its jurisprudence, the CJEU has traditionally opted for a "broad" definition of the concept of undertaking. In particular, rather than referring to national (diverging) definitions, the Court shaped an EU concept of undertaking, defined as any "entity performing an economic activity". Via this broad definition, the Court aimed at covering under the scope of the Treaty both private and State-owned undertakings. Only public entities that exercised States' sovereign powers (e.g. military activities, policy and administration of justice) clearly fell outside the definition of undertaking and, thus, the scope of the Treaty. Secondly, the Court stressed in its jurisprudence that the entity could be considered an undertaking, subject to the application of the Treaty, even if the latter was not classified as a firm under national corporate law. ${ }^{5}$ Finally, the concept of "economic activity" implied that the entity sold a good/service in the market, ${ }^{6}$ but it did not require the entity to necessarily make any profit out of the activity. ${ }^{7}$ As a consequence of this broad definition, in Montessori, for example, the EU General Court recognised that a private elementary school was an

\footnotetext{
${ }^{3}$ In the Treaty on the Functioning of the European Union (TFEU), the word "undertaking(s)" is repeated 52 times.

Consolidated version of the Treaty on the Functioning of the European Union. OJ C-326/47, 26.10.2012.

${ }^{4}$ Judgment of 23 April 1991, Klaus Höfner and Fritz Elser v. Macrotron GmbH, C-41/90, ECLI:EU:C:1991:161, paragraph 21.

5 "The concept of undertaking encompasses every entity engaged in an economic activity, regardless of the legal status of the entity and the way in which it is financed". Ibid.

${ }^{6}$ Judgment of 12 September 2000, Pavel Pavlov and Others v. Stichting Pensioenfonds Medische Specialisten, C-180/98, ECLI:EU:C:2000:428, paragraph 75.

${ }^{7}$ Judgment of 1 July 2008, Motosykletistiki Omospondia Ellados NPID (MOTOE) v. Elliniko Dimosio, C-49/07, ECLI:EU:C:2008:376, paragraph 27.
} 
undertaking within the scope of the Treaty, since the school provided an educational service though it did not make any profit. ${ }^{8}$

In line with this broad definition, in Estaciones de Servicios the Court further clarified that an undertaking is "any economic entity, even if, from a legal perspective, that unit is made up of a number of natural or legal persons". 'According to the CJEU, a "single economic entity" may include the mother company and its subsidiaries, which are thus considered a single undertaking under the Treaty. The Court followed a functional definition of undertaking: since the mother company and its subsidiaries do not compete in the market, they should be considered part of the same entity. ${ }^{10}$ Since its early case law, the Court thus introduced an innovative approach to consider multinational corporations as single economic entities; an approach that clearly diverges from national corporate law, which usually considers each sub-unit of these complex organisational structures as a separate firm.

The single economic entity doctrine has had important implications for the enforcement of EU competition law. First of all, in Imperial Chemical the Court of Justice recognised the joint parent-subsidiary liability in EU competition law. According to the Court, since "the subsidiary does not decide independently upon its own conduct on the market but carries out (...) the instructions given by the parent company", the latter company should be liable for the breaches of EU competition law carried out by its subsidiary. ${ }^{11}$ Via this functional approach, the Court increased the deterrent effect of the sanctions imposed by the Commission for violations of EU competition law. Via the joint parent-subsidiary liability, in fact, the Commission would calculate the amount of the fine not only based on the annual turnover of the firm directly involved in a breach of EU competition rules (e.g. a cartel), but on the basis of the turnover of the entire economic group.

In its case law, the Court of Justice has clarified that the joint parentsubsidiary liability exists only if the mother company exercises a "control"

\footnotetext{
${ }^{8}$ Judgment of 15 September 2016, Scuola Elementare Maria Montessori Srl v. European Commission, T-220/13, ECLI:EU:T:2016:484, paragraph 137.

${ }^{9}$ Judgment of 14 December 2006, Confederación Española de Empresarios de Estaciones de Servicio v. Compañía Española de Petróleos SA, C-217/05, ECLI:EU:C:2006:784, paragraph 40.

${ }^{10}$ Okeoghene Odudu and David Bailey, "The single economic entity doctrine in EU competition law”, Common Market Law Review 51 (2014): 1729.

${ }^{11}$ Judgment of 14 July 1969, Imperial Chemical Industries Ltd. v. Commission, C-48/69, ECLI:EU:C:1972:70, paragraph 132.
} 
over its subsidiary. ${ }^{12}$ In particular, if the parent company is the only shareholder of the subsidiary (i.e. it holds $100 \%$ of its shares), there is a presumption that the parent company has full control of the subsidiary's activities, and thus it was aware of the breach of EU competition rules carried out by the subsidiary. ${ }^{13}$ By contrast, the Commission has the burden of proof of showing the presence of control in the other cases. In particular, the Commission can look at the institutional control (e.g. how many representatives the mother company can appoint in the board of the subsidiary), rather than at the effective exercise of control. ${ }^{14}$ In other words, the Commission can prove that the mother company is jointly liable by looking at the governance structure of the subsidiary, without the need to find direct evidence that the mother company directly ordered the subsidiary to engage in an anti-competitive practice.

The single economic doctrine has been debated for a number of years in the literature; a number of arguments have been put forward in favour and against such doctrine. Besides the increased deterrent effect against possible violations of $\mathrm{EU}$ competition rules, a positive effect of this doctrine is that it forces the parent company to actively monitor its subsidiary in order to avoid a competition law violation. ${ }^{15}$ On the other hand, a number of authors have argued that the deterrent effect of the single economic entity doctrine is limited in practice. The Commission, in fact, rarely imposes the maximum fine provided under Art. 23(2) Reg. 1/2003 (i.e. 10\% of the annual turnover of the undertaking). ${ }^{16}$ In particular, firms have often relied on the "inability to pay" argument in order to ask the Commission for a fine reduction. ${ }^{17}$ Besides its limited impact on fines, the single economic entity doctrine would not necessarily strengthen the monitoring activities of the parent company over its subsidiary, since antitrust compliance

\footnotetext{
${ }^{12}$ Judgment of 14 July 1969, Imperial Chemical Industries Ltd. v. Commission, C-48/69, ECLI:EU:C:1972:70, paragraph 133.

${ }^{13}$ Judgment of 10 September 2009, Akzo Nobel NV and Others v. Commission, C-97/08 P, ECLI:EU:C:2009:536, paragraph 62.

${ }^{14}$ Aitor Montesa, and Angel Givaja, "When parents pay for their children's wrongs: Attribution of liability for EC antitrust infringements in parent-subsidiary scenarios", World Competition 29, no. 4 (2006): 566.

${ }^{15}$ Carsten Koenig, "An economic analysis of the single economic entity doctrine in EU competition law", Journal of Competition Law and Economics 13, no. 2 (2017): 295.

${ }^{16}$ Council Regulation (EC) No. 1/2003 of 16 December 2002 on the implementation of the rules on competition laid down in Articles 81 and 82 of the Treaty. OJ L-1/1, 4.1.2003. Art. 23(2).

${ }^{17}$ Koenig, "An economic analysis of the single economic entity doctrine in EU competition law": 305.
} 
programmes have become a rather common practice in every corporation, even in the lack of a joint parent-subsidiary liability. ${ }^{18}$ Thirdly, as further discussed in the following sections in relation to Skanka Industrial, the single economic entity doctrine deviates from the principle of individual firm liability, a core principle of every national corporate law. ${ }^{19}$ Finally, the single economic entity doctrine might also affect the parent company value when its shares are traded in financial markets. ${ }^{20}$ In particular, (small) shareholders of the mother company are usually not aware of anti-competitive practices carried out by one of its subsidiaries. However, an antitrust fine might negatively affect the annual profits of the mother company, and thus the shareholders' dividends.

Besides the joint parent-subsidiary liability, another important consequence of the single economic entity doctrine is the extension of the antitrust liability in case of corporate restructuring. As recognised by the CJEU in ETI, "when an entity that has committed an infringement of the competition rules is subject to a legal or organisational change, this change does not necessarily create a new undertaking free of liability for the conduct of its predecessor that infringed the competition rules". ${ }^{21}$

Similar to the joint parent-subsidiary liability, the so-called "economic succession doctrine" has primarily a deterrent goal: it aims at avoiding that a firm carries out a corporate restructuring (e.g. transfers its assets to a different legal entity) in order to escape from the payment of the antitrust fine. ${ }^{22}$ Due to the progressive increase of the antitrust fines recorded in recent years, such scenario is not so remote; as further discussed in section III, it is at the core of the Skanska Industrial case. As mentioned above in relation to the joint parent-subsidiary liability, the economic succession doctrine represents a major deviation from the principle of individual firm responsibility enshrined in national corporate law and, thus, generates a potential conflict between national and EU law.

The CJEU's jurisprudence discussed in the previous paragraphs refers to the Commission's power to enforce EU competition rules. While the joint parent-company liability and the economic succession doctrine are

\footnotetext{
${ }^{18}$ Koenig, "An economic analysis of the single economic entity doctrine in EU competition law": 309.

${ }^{19}$ James Hennah, "The role of undertakings in private law following Shanska", Global Competition Law Review 12, no. 2 (2019): 75.

${ }^{20}$ Koenig, "An economic analysis of the single economic entity doctrine in EU competition law": 318.

${ }^{21}$ Judgment of 11 December 2007, Autorità Garante della Concorrenza e del Mercato v. Ente tabacchi italiani - ETI SpA, C-280/06, ECLI:EU:C:2007:775, paragraph 42.

${ }^{22}$ Montesa and Givaja, "When parents pay for their children's wrongs": 559.
} 
well-established principles in relation to the Commission's enforcement powers of EU competition rules, such principles are mostly unknown in the national competition law of the majority of the Member States. This is due to the principle of individual firm responsibility that usually characterises national corporate law. A good example is represented by the Sausages case: in 2014, the Bundeskartellamt sanctioned 21 sausages manufacturers involved in a price-fixing cartel, imposing a record fine of $€ 338$ million. ${ }^{23}$ After the imposition of the fine, 3 firms sanctioned by the German National Competition Authority (NCA) transferred their assets to other firms, members of the same economic groups. Due to the lack of the single economic entity doctrine in German law, in 2016 the Bundeskartellamt stopped the fining proceedings in relation to the 3 firms involved in the corporate restructuring. ${ }^{24}$

The Sausages case had major policy repercussions, both in Germany and in the EU. In June 2017, the German Act Against Restraints of Competition (GWB) was amended, in order to implement the Damages Directive. ${ }^{25}$ In particular, a new Section 81(3)(a) GWB was introduced. The latter provision mentions that the Bundeskartellamt may also impose fines on the legal persons "which continued to operate the undertaking in economic continuity". The provisions did not transpose the Damages Directive, but rather aimed at reacting to the legal loophole identified by the Sausages case by introducing for the first time the single economic doctrine in the German competition law.

The Sausages case had also broader policy repercussions at the EU level: the ECN+ Directive adopted in December 2018, in fact, introduces the single economic entity in the national competition law of every Member State. ${ }^{26}$ In particular, the preamble of the ECN + Directive recognises that "the notion of 'undertaking' (...) should be applied in accordance with the case law of the Court of Justice. Accordingly, NCAs should be able to apply

\footnotetext{
23 "Bundeskartellamt imposes fines on sausage manufacturers". https://www.bundeskartellamt.de/ SharedDocs/Meldung/EN/Meldungen\%20News\%20Karussell/15_07_2014_Wurst.html.

24 "Proceedings against companies of Clemens Tönnies group concluded - fines of 128 million euros cancelled due to restructuring measures". https://www.bundeskartellamt.de/SharedDocs/ Meldung/EN/Pressemitteilungen/2016/19_10_2016_Wurst.html.

${ }^{25}$ An official English translation of the GWB is available at http://www.gesetze-im-internet.de/ englisch_gwb/.

${ }^{26}$ Directive (EU) 2019/1 of the European Parliament and of the Council of 11 December 2018 to empower the competition authorities of the Member States to be more effective enforcers and to ensure the proper functioning of the internal market. OJ L-11/3, 14.1.2019.
} 
the notion of undertaking to find a parent company liable, and impose fines on it, for the conduct of one of its subsidiaries, where the parent company and its subsidiary form a single economic unit". ${ }^{27}$

In addition, similarly to Art. 23(2) Reg. 1/2003, Art. 15 ECN + Directive recognises that NCAs can impose a fine up to $10 \%$ of the annual worldwide turnover of the "undertakings" involved in a competition infringement i.e. the broad concept of "undertaking" developed by CJEU case law is thus transposed into national competition law.

The ECN+ Directive leads to the extension of the single economic entity doctrine in every EU Member State. Consequently, every NCA will also apply the joint parent-subsidiary liability and the economic succession doctrine when they enforce Arts. 101 and 102 TFEU at the national level. EU Member States have to transpose the ECN + Directive into national competition law by February 2021. ${ }^{28}$

\section{Skanska Industrial}

The CJEU case law concerning the single economic entity doctrine concerns the EU Commission power to enforce Arts. 101 and 102 TFEU (i.e. public enforcement of EU competition law). The ECN + Directive has extended such case law to the power of NCAs in enforcing national competition law. By contrast, the ECN + Directive does not deal with damage claims started in national civil courts in relation to a breach of EU competition rules. Similarly, the Damages Directive recognised the joint liability of cartelists in the contest of damage claims, ${ }^{29}$ but it did not expressly mention either the joint parent-subsidiary liability or the economic succession doctrine. The Damages Directive refers to the expression "undertaking" without, however, providing a clear definition of this concept. ${ }^{30}$

As discussed in the following sub-section, the uncertainty linked to the application of the single economic entity doctrine in the contest of private enforcement of EU competition law led the Finnish Supreme Court to refer a preliminary ruling question to the CJEU in the contest of the Skanska

\footnotetext{
${ }^{27}$ Directive 2019/1, preamble, paragraph 46.

${ }^{28}$ Directive 2019/1, Article 34.

${ }^{29}$ Directive 2014/104 (EU) of the European Parliament and of the Council of 26 November 2014 on certain rules governing actions for damages under national law for infringements of the competition law provisions of the Member States and of the European Union. OJ L-349/1, 5.12.2014. Art. 11.

${ }^{30}$ Article 2 of Directive 2014/104 includes a list of definitions relevant for the Directive, but it does not refer to the concept of "undertaking".
} 
Industrial case. The case represents well how the single economic entity doctrine, and its consequence in terms of economic succession doctrine, conflict with the principle of individual firm liability enshrined in national corporate law. ${ }^{31}$

\section{III.1 Skanska Industrial - proceedings at the national level}

Skanska Industrial originates from the Asphalt legal saga, a major cartel case which kept the Finnish courts busy during the past decade. After years of investigations, in 2004 the Finnish Competition and Consumer Authority successfully referred the case to the Market Court. ${ }^{32}$ The latter imposed a fine on several Finnish companies involved in a bid rigging cartel affecting the road construction industry between 1999 and $2002 .{ }^{33}$ In 2009, the Finnish Supreme Administrative Court upheld the previous ruling of the Market Court. ${ }^{34}$

The judgment of the Finnish Supreme Administrative Court concluded the public enforcement side of this legal saga, and it opened the private enforcement one: 39 cities started a follow-on damage actions against the cartelists, relying on the 2009 judgment as res judicata. In particular, the city of Vanta started a damage claim at the Helsinki District Court against a number of cartelists, including Skanska Industrial. ${ }^{35}$

During the years following the cartel discovery by the Finnish NCA, most of the companies involved in the cartel started a process of corporate restructuring. In particular, Skanska Asfaltti Oy acquired all the shares of Sata-Asfaltti, one of the firms originally involved in the cartel, which had started a voluntary liquidation procedure. Skanska Asfaltti Oy later changed its legal name into Skanska Industrial Solution, the main claimant in the case brought to the CJEU for preliminary ruling. ${ }^{36}$

\footnotetext{
${ }^{31}$ Hennah, "The role of undertakings in private law following Shanska": 75.

32 "FCA's finishes asphalt cartel investigations". Finnish Competition and Consumer Authority. https:/www.kkv.fi/en/current-issues/press-releases/finnish-competition-authority/2003/fcasfinishes-asphalt-cartel-investigations/

${ }^{33}$ Judgment of 19 December 2007, Finnish Market Court decision 94/04/KR.

${ }^{34}$ Judgment of 14 March 2019, Vantaan kaupunki v. Skanska Industrial Solutions Oy e a., C-724/17, ECLI:EU:C:2019:204, paragraph 10.

${ }^{35}$ John Connor and Toni Kalliokoski, “The Finnish Asphalt Cartel court decision on damages: An important EU precedent and victory for plaintiffs", CPI Antitrust Chronicle, February (2014): 1.

${ }^{36}$ Opinion of Advocate General Wahl of 6 February 2019, Vantaan kaupunki v. Skanska Industrial Solutions Oy e a., C-724/17, ECLI:EU:C:2019:100.
} 
Helsinki District Court upheld the damage claim against Skanska Industrial. In particular, the court referred to the principle of full effectiveness of EU law in order to justify the application of the economic succession doctrine in the case, though the latter doctrine did not exist under Finnish civil law. ${ }^{37}$

In 2013, Helsinki Court of Appeal dismissed the damage claim, relying on the defendant argument that Finnish civil law did not recognise the principle of economic continuity, which was thus not applicable in the case. $^{38}$

In view of the diverging rulings by the two lower courts, the Finnish Supreme Court decided to stay at proceedings and refer three questions for preliminary ruling to the CJEU. ${ }^{39}$ In essence, the Supreme Court asked the Court of Luxembourg to clarify whether the economic succession doctrine was applicable to damage claims arising from a breach of EU competition rules.

\section{III.2 The AG's opinion in Skanska Industrial}

AG Wahl delivered his opinion on the case on 6 February $2019 .{ }^{40}$ In his opinion, the AG referred to the well-established Manfredi case law, ${ }^{41}$ whereby "any individual" has the right to claim compensation for the harm caused by a breach of Arts. 101 and 102 TFEU..$^{42}$ Although it is up to the Member States to define the rules applicable to damage claims (i.e. principle of procedural autonomy), such rules cannot jeopardise the "full effectiveness" of EU competition rules. According to the Advocate General, a national rule that allowed a cartelist to escape from the payment of a damage compensation via a simple corporate restructuring did not "ensure an individual

\footnotetext{
${ }^{37}$ Judgment of 14 March 2019, Vantaan kaupunki v. Skanska Industrial Solutions Oy e a., C-724/17, ECLI:EU:C:2019:204, paragraph 12.

${ }^{38}$ Judgment of 14 March 2019, Vantaan kaupunki v. Skanska Industrial Solutions Oye a., C-724/17, ECLI:EU:C:2019:204, paragraph 13.

${ }^{39}$ Judgment of 14 March 2019, Vantaan kaupunki v. Skanska Industrial Solutions Oy e a., C-724/17, ECLI:EU:C:2019:204, paragraph 22.

${ }^{40}$ Opinion of Advocate General Wahl of 6 February 2019, Vantaan kaupunki v. Skanska Industrial Solutions Oy e a., C-724/17, ECLI:EU:C:2019:100.

${ }^{41}$ Opinion of Advocate General Wahl of 6 February 2019, Vantaan kaupunki v. Skanska Industrial Solutions Oy e a., C-724/17, ECLI:EU:C:2019:100, paragraph 30.

${ }^{42}$ Judgment of $13^{\text {th }}$ July 2006, Vincenzo Manfredi v. Lloyd Adriatico Assicurazioni SpA, C-295/04, ECLI:EU:C:2006:461, paragraph 59.
} 
right to compensation". ${ }^{43}$ According to the AG, in order to safeguard the full effectiveness of EU competition law enforcement, the "determination of the persons liable" for a breach of EU competition rules should be a uniform concept under EU law, rather than left to the procedural autonomy of EU Member States. ${ }^{44}$ The Advocate General thus concluded that "there is nothing extraordinary" in recognising the economic succession doctrine in the context of damage claims of EU competition law. ${ }^{45}$

Indeed, the AG's opinion is nothing extraordinary in recognising the application of the economic succession doctrine; it builds upon the traditional line of reasoning followed by the CJEU since Courage v. Crehan to set aside national procedural rules that could hamper the "full effectiveness" of private enforcement of EU competition law. ${ }^{46}$ More interesting is the additional consideration put forward by the Advocate General concerning the nature of damage claims. In his opinion, the AG recognised the complementarity of public and private enforcement of EU competition rules, emphasising that damage claims have a "deterrent" effect in relation to future competition law violations. ${ }^{47}$ Nevertheless, the CJEU has never accepted the "deterrent" effect of damage claims: an American approach to private enforcement of antitrust law that conflicts with the compensatory nature of damage claims in Europe.

\section{III.3. The CJEU ruling in Skanska Industrial}

The CJEU delivered its ruling in Skanska Industrial on 14 March 2019. ${ }^{48}$ The final judgment of the Court is indeed "nothing extraordinary": in line with the AG's opinion, the CJEU referred in its previous case law concerning the "full effectiveness" of EU law in order to recognise the economic succession doctrine in damage claims concerning a breach of EU competition rules. In particular, the Court argued that "the concept

\footnotetext{
${ }^{43}$ Opinion of Advocate General Wahl of 6 February 2019, Vantaan kaupunki v. Skanska Industrial Solutions Oy e a., C-724/17, ECLI:EU:C:2019:100, paragraph 78

${ }^{44}$ Opinion of Advocate General Wahl of 6 February 2019, Vantaan kaupunki v. Skanska Industrial Solutions Oy e a., C-724/17, ECLI:EU:C:2019:100, paragraphs 66-67

${ }^{45}$ Opinion of Advocate General Wahl of 6 February 2019, Vantaan kaupunki v. Skanska Industrial Solutions Oy e a., C-724/17, ECLI:EU:C:2019:100, paragraph 80

${ }^{46}$ Judgment of 20 September 2001, Courage Ltd v. Bernard Crehan, C-453/99, ECLI:EU:C:2001:465, paragraphs 24-26.

${ }^{47}$ Opinion of Advocate General Wahl of 6 February 2019, Vantaan kaupunki v. Skanska Industrial Solutions Oy e a., C-724/17, ECLI:EU:C:2019:100, paragraphs 46-47.

${ }^{48}$ Judgment of 14 March 2019, Vantaan kaupunki v. Skanska Industrial Solutions Oy e a., C-724/17, ECLI:EU:C:2019:204.
} 
of 'undertaking' within the meaning of Article 101 TFEU, which constitutes an autonomous concept of EU law, cannot have a different scope with regard to the imposition of fines by the Commission under Article 23(2) of Reg. 1/2003 as compared with actions for damages for infringement of EU competition rules". ${ }^{49}$

As a consequence, CJEU case law concerning the economic succession doctrine, deriving from the broad definition of "undertaking" within public enforcement of EU competition rules, was also applicable to damage claims for breaches of Arts. 101-102 TFEU.

Since the Court simply referred to its previous case law, Skanska Industrial was decided by the single, rather than the grand chamber. ${ }^{50}$ Overall, the Court followed the line of reasoning proposed by the Advocate General. On the other hand, unlike the AG's opinion, the Court confined its ruling to the question asked by the Finnish Supreme Court, without discussing the deterrent effect of damage claims.

\section{Skanska Industrial: consequences and open questions}

As discussed in the previous section, Skanska Industrial generated a long and intense judicial debate among Finnish civil courts on the application of the economic succession doctrine: a legal concept developed by the CJEU in the context of public enforcement of EU competition law, but an "alien" to the civil law systems of the majority of EU Member States, like Finland. ${ }^{51}$ However, both the Advocate General and the CJEU found "nothing extraordinary" in recognising such doctrine in the context of damage claims concerning a breach of EU competition rules.

In spite of the short length of the judgment, Skanska Industrial might have important consequences in the coming years. In particular, the ruling might incentivise the number of damage claims in the future, avoiding corporate restructuring from representing a procedural obstacle to the identification of the legal entity liable to pay the damage compensation. The extended liability introduced by Skanska Industrial will also have a consequence in the context of corporate acquisitions: the acquiring

\footnotetext{
${ }^{49}$ Judgment of 14 March 2019, Vantaan kaupunki v. Skanska Industrial Solutions Oy e a., C-724/17, ECLI:EU:C:2019:204, paragraph 47.

${ }^{50}$ Lena Hornkohl, "The economic continuity test in private enforcement of competition law - the ECJ's judgment in Skanska Industrial Solutions”, European Competition Law Review 40, no. 7 (2019): 343.

${ }^{51}$ Hennah, "The role of undertakings in private law following Shanska": 75.
} 
company will have to carefully scrutinise the previous antitrust liability of the acquired firms, since it it might be asked to pay compensation in the context of a possible damage claim. ${ }^{52}$ Therefore, antitrust due diligence will become particularly important in the context of any corporate acquisition.

Although the approach followed by the CJEU in Skanska Industrial aimed at promoting damage claims, a number of issues remain open after the judgment. First of all, although the successor company will be potentially liable for a breach of EU competition rules, it will not necessarily have access to the evidence concerning the infringement carried out by the economic predecessor. ${ }^{53}$ In other words, although a claimant might ask the judge to order the successor company to disclose certain documents concerning the competition law infringement, ${ }^{54}$ the successor company might simply not have such documents. As a consequence, the defendant will have to prove not to be in possession of the requested documents. On the other hand, in spite of the prima facie liability of the successor company, the claimant will not be able to collect important evidence from the defendant to quantify the suffered harm and to establish its causal link with the alleged infringement. Such problem will be particularly relevant in stand-alone, rather than in follow-on actions. In the first type of damage actions, in fact, the claimant heavily relies on the disclosure of evidence ordered by the court.

An issue that the CJEU has not clarified in Skanska Industrial concerns the "limits" of the economic succession doctrine in the context of damage claims. As argued in section II, in ETI the CJEU recognised that a corporate restructuring does not necessarily create a "new undertaking" free from the antitrust liability of its predecessor. ${ }^{55}$ Indeed, in Skanska Industrial the firm simply changed its legal name in order to escape from the payment of the fine imposed by the Finnish NCA and the possible damage compensation. However, corporate restructuring could be more complex:

\footnotetext{
${ }^{52}$ Hennah, "The role of undertakings in private law following Shanska": 79.

${ }^{53}$ Hennah, "The role of undertakings in private law following Shanska": 79.

${ }^{54}$ It is worth noticing that Article 5(2) of the Damages Directive has harmonised and strengthened the power of national civil courts in ordering the disclosure of evidence in the context of antitrust damage claims. In particular, national courts can "order the disclosure of specified items of evidence or relevant categories of evidence circumscribed as precisely and as narrowly as possible on the basis of reasonably available facts in the reasoned justification".

Directive 2014/104, Article 5(2).

${ }_{55}$ Judgment of 11 December 2007, Autorità Garante della Concorrenza e del Mercato v. Ente tabacchi italiani - ETI SpA, C-280/06, ECLI:EU:C:2007:775, paragraph 42.
} 
establishing whether the new legal entity is indeed a "new undertaking", rather than a successor of the previous firm, is not always a straightforward exercise. ${ }^{56}$ In the context of corporate restructuring, for instance, other investors might become additional shareholders of the firm. Alternatively, the firm could sell a subsidiary previously involved in an antitrust violation. The types of corporate restructuring are numerous, and it is unthinkable that the economic succession doctrine could be applicable in every case. As discussed in section II, the CJEU has recognised the joint parentsubsidiary liable only when the mother company exercises a control over the subsidiary - i.e. when the parent company could not be unaware of the competition law breach by its subsidiary. In the context of the economic succession doctrine, the CJEU has not introduced a similar case law. Therefore, the CJEU might be called, in the coming years, to clarify Skanska Industrial case law, further explaining the conditions where a corporate restructuring indeed leads to a "new undertaking" free from the antitrust liability acquired from the predecessor.

The last question that remains open after Skanska Industrial concerns its scope of application: should the economic succession doctrine be applicable only to damage claims? Alternatively, should this doctrine be applicable to the other categories of remedies under private enforcement of EU competition law (i.e. actions requesting a court injunction, compensation for unjust enrichment, declaration that a contract is null and void)? As discussed in section III, Skanska Industrial was a follow-on damage claim. Consequently, in its preliminary ruling, the CJEU only referred to damage actions. In Skanska Industrial, however, the Court relied on the general principle of full effectiveness and the uniform concept of "undertaking" under EU law, rather than on the Damages Directive. Damage claims are a sub-category in private enforcement of competition law; a category that has been extensively harmonised at the EU level during the past decade. Nevertheless, in principle, there would be no reason to exclude a priori the application of the economic succession doctrine to other types of remedies in the context of private enforcement of EU competition rules. As in Courage v. Crehan, ${ }^{57}$ for example, a complainant could ask the court to declare an exclusive distribution agreement null and avoid for being in breach of EU competition rules. In light of

\footnotetext{
${ }^{56}$ Aidan Robertson, "Skanska Industrial Solutions: What does the Court of Justice's landmark judgment mean for cartel damages litigation?", European Competition Law Review 40, no. 8 (2019): 350. ${ }^{57}$ Judgment of 20 September 2001, Courage Ltd v. Bernard Crehan, C-453/99, ECLI:EU:C:2001:465.
} 
the economic successor doctrine, this remedy would be applicable even if the agreement had been concluded between the complainant and the "predecessor" firm, and later inherited by the defendant as a consequence of a corporate restructuring.

\section{Conclusions}

In Skanska Industrial the CJEU recognised the economic succession doctrine in damage claims for breaches of EU competition rules on the basis of its well-established case law. From this point of view, the ruling is indeed "nothing extraordinary". Nevertheless, the judgment represents an important milestone that contributes to the development of damage claims in Europe.

A number of questions, however, remain open after the judgment. In particular, it remains unclear how the disclosure of evidence will take place in practice in the context of a damage claim following a corporate restructuring. Secondly, the limits of the economic succession doctrine still remain unclear: it is unclear when a corporate restructuring indeed leads to the establishment of a "new" undertaking, free from the antitrust liability acquired by its predecessor. Finally, it remains unclear whether Skanska Industrial case law could also be extended to other remedies besides damage claims, such as actions requesting a court injunction, compensation for unjust enrichment, or a declaration that a contract is null and void.

Skanska Industrial is thus an interesting ruling that confirms a wellestablished approach by the CJEU, eager to harmonise via its preliminary rulings "bits and pieces" of national procedural rules applicable to damage claims for breaches of EU competition rules. However, the judgment raises a number of questions which will probably have to be answered by the Court in further preliminary rulings in the coming years.

\section{Bibliography}

Connor, John and Toni Kalliokoski. “The Finnish Asphalt Cartel court decision on damages: An important EU precedent and victory for plaintiffs". CPI Antitrust Chronicle, February (2014): 1-18.

Hennah, James. "The role of undertakings in private law following Shanska". Global Competition Law Review 12, no. 2 (2019): 75-80.

Hornkohl, Lena. "The economic continuity test in private enforcement of competition law - the ECJ's judgment in Skanska Industrial Solutions". European Competition Law Review 40, no. 7 (2019): 340-343. 
Koenig, Carsten. "An economic analysis of the single economic entity doctrine in EU competition law". Journal of Competition Law and Economics 13, no. 2 (2017): 281-327. Montesa, Aitor and Angel Givaja. "When parents pay for their children's wrongs: Attribution of liability for EC antitrust infringements in parent-subsidiary scenarios". World Competition 29, no. 4 (2006): 555-574.

Odudu, Okeoghene and David Bailey. "The single economic entity doctrine in EU competition law”. Common Market Law Review 51 (2014): 1721-1758.

Robertson, Aidan. "Skanska Industrial Solutions: What does the Court of Justice's landmark judgment mean for cartel damages litigation?" European Competition Law Review 40, no. 8 (2019): 347-353. 